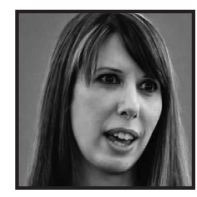

\title{
Commentary Fiction as a Transformative Tool
}

\author{
Patricia Leavy
}

\begin{abstract}
This piece explores the potential of fiction as a powerful pedagogical tool within and beyond the academy. Drawing on professors' examples, literary neuroscience, and my experience as an author of sociological fiction and editor of the Social Fictions book series, I suggest how fiction can be used to foster critical thinking, consciousnessraising, forge micro-macro connections, engage learners in deep reflection, teach substantive content, and promote understanding and empathy across differences.
\end{abstract}

he arts can be used as powerful tools in research and teaching.
Arts-based research practices (ABR) are tools that adapt the creative arts
in research across the disciplines (Leavy, 2009, 2015b). ABR can be used to make research accessible and engaging. Further, as a pedagogical tool it can transform passive learning into active, and even joyful learning. Renowned scholar Maxine Greene (2008) advocated "aesthetic education" to promote student engagement and foster imagination.

Fiction is one genre with enormous potential to transform understanding and deepen engagement. I have written extensively about fiction as a research practice or fiction-based research (see Leavy 2013b, 2015b), which I view as fiction that is informed by or grounded in scholarship. In this brief commentary I focus on the unique capabilities of fiction in teaching and learning, which is also a subject near and dear to me. However, I intend a broad definition of teaching and learning that is not bound to the academy. Under this conception, learning may occur with students in classroom settings or lay citizens engaging with public scholarship (including fictionbased research). This is one of the beauties of fiction: it's jargon-free, accessible, and experienced as enjoyable by the many, not the few. 
In classroom settings, Colin Irvine (2008) suggests that students are likely to see novels, particularly if selected well, as relevant to their lives. Learning that is relevant to people's lives is more likely to engage them (Leavy, 2013b). Fiction can be used to foster critical thinking, consciousness-raising, forge micro-macro connections, teach substantive content, and promote understanding and empathy across differences. Why does fiction hold so much potential for transformative learning? When we're reading a short story or novel that we enjoy, we can become immersed in the story world. Many of us can relate to the feeling that the house could burn down when you're reading a good novel and you wouldn't notice, or you go to bed later and later because you just have to see what happens. We can relate because there is actually neuroscience to help explain our immersion in fiction.

"Literary neuroscience," a growing field that explores the connections between our brains and literature, has produced fascinating research that may explain why fiction is a particularly effective learning tool. Research in this field suggests our brains function differently when reading fiction (as compared to nonfiction) and that the effects of reading fiction last longer.

Natalie Phillips (2012) conducted a study about how reading affects the brain (see Thompson \& Vedantam, 2012). She became interested in studying "distractibility" based on her personal experiences and observations. Phillips explains:

I love reading, and I am someone who can actually become so absorbed in a novel that I really think the house could possibly burn down around me and I wouldn't notice. And I'm simultaneously someone who loses their keys at least three times a day, and I often can't remember where in the world I parked my car. (quoted in Thompson \& Vedantam, 2012)

Phillips led a research team to measure brain activity as research participants engaged in close versus casual reading of a Jane Austen novel. The preliminary results indicated that the entire brain appears to be transformed as people engage in close readings of fiction. Moreover, there appear to be global activations across a number of different regions of the brain, including some unexpected areas such as those that are involved in movement and touch. In the experiment, it was as if "readers were physically placing themselves within the story as they analyzed it" (Thompson \& Vedantam, 2012). In another example, Gregory Berns (2013) led a team of researchers in a study published in Brain Connectivity that suggests there is heightened connectivity in our brains for days after reading a novel. Thus, the feeling of immersion and deep engagement we have in a good work of fiction (good meaning one we enjoy), 
is partly a result of physiologically changes in our brain stimulated by the fiction. The potential for teaching and learning through fiction is immense.

Many high school teachers use novels to teach a variety of subjects. For example, historical novels can be used to bring primary source material to life. Now, it seems more university professors across the disciplines are also incorporating fiction into their classrooms, and sharing about the positive outcomes. Here are just a few examples from the social sciences and gender studies in which professors have written about positive learning outcomes.

Sociologist Kristina B. Wolff (2008) uses novels to help beginning students forge micro-macro connections. Similarly, sociologist Peter P. Nieckarz Jr. (2008) uses novels in intro-level general education courses to offer students with limited life experiences more material to draw on as they build an understanding of the social world. Some psychology professors use novels in lieu of case studies. For example, Joan Chrisler (1990) asks her students to examine the main character of a novel who is dealing with mental illness; William Tucker (1994) has his students read short stories in order to consider what conducting therapy with the characters would be like; and Dana Dunn (1999) uses fiction to explore a range of topics including the nature of the self, stress and coping, and issues related to aging (Grosofsky, 2008). Psychologist Hillary Lips (1990) uses science fiction in order to explore gender-based assumptions students typically take for granted (Grosofsky, 2008). Mary Crawford (1994) has students read romance novels in order to investigate gender stereotypes (Grosofsky, 2008). Amy C. Branam (2008) uses novels in a general education course in order to illustrate the idea of women in literature. Sandra L. Faulkner (2013) uses short stories and novels in her communication courses to teach about relationships and relational processes (Leavy, 2013b). Again, these are just examples.

In 2011 I created and launched the Social Fictions book series with Sense Publishers (I serve as series editor). The series publishes scholarship written entirely in literary forms including novels, plays, short story and poetry collections. Our intent is to produce books for both classroom and popular use. I began the series as a way to house my first novel, Low-Fat Love, which was inspired by nearly a decade of sociological interview research with women. Since then we have published a total of 19 books, including an anniversary edition of my first novel as well as my novels, American Circumstance (2013a) and Blue (2015a), each inspired by my research, teaching, and personal experiences. As both an author and series editor I have received countless emails and notes from readers, students, and lay citizens. Readers' responses to fiction are incomparable with their responses to nonfiction. ${ }^{1}$ People often reveal an emotional 
connection to what they have read, recount what resonated with them, demonstrate a lasting memory of and engagement with even minute details, and express personal change and growth related to the reading. These sentiments have been expressed by both students and lay readers exposed to the same work, often one reading for an assignment and another for leisure. This suggests the power of fiction and fiction-based research to reach and move multiple audiences, transcending popular misnomers that learning is reserved for school and dusty "big word" books, as ironically I wrote in one of my novels. ${ }^{2}$

\section{Notes}

1. I also edit five nonfiction book series and have published numerous nonfiction books of my own from which I can draw a comparison to the response to the Social Fictions series.

2. I am referring to my novel, Blue (2015, Sense Publishers).

\section{References}

Berns, G. S., Blaine, K., Prietula, M. J., \& Pye, B. E. (2013). Short- and long-term effects of a novel on connectivity in the brain. Brain Connectivity, 3(6), 590-600.

Branam, A. C. (2008). Reading Wollstonecraft's Maria from cover to cover and back again: The novel in the general education course. In C. C. Irvine (Ed.), Teaching the novel across the curriculum: A handbook for educator (pp. 13-27). Westport, CT: Greenwood Press.

Chrisler, J. C. (1990). "Novels as case study materials for psychology students." Teaching of Psychology, 17(1), 55-57.

Dunn, D. S. (1999). Interpreting the self through literature: Psychology and the novels of Wallace Stegner. In L. T. Benjamin, B. F. Nodine, R. M. Ernst, and C. B. Broeker (Eds.), Activities Handbook for the Teaching of Psychology (pp. 362-365). Washington, DC: American Psychological Association.
Greene, M. (2008). "Commentary. Education and the arts: The windows of imagination." LEARNing Landscapes, 2(1), 17-21.

Grosofsky, A. (2008.) Stories in psychology: Sensation and perception. In C. C. Irvine (Ed.), Teaching the novel across the curriculum: A handbook for educators (pp. 272-277). Westport, CT: Greenwood Press.

Irvine, C. C. (2008). Introduction. In C. C. Irvine (Ed.),Teaching the novel across the curriculum: A handbook for educators (pp. 1-11). Westport, CT: Greenwood Press.

Leavy, P. (2009). Method meets art: Arts-based research practice. New York: Guilford Press.

Leavy, P. (2011). Low-fat love. Rotterdam, The Netherlands: Sense Publishers.

Leavy, P. (2013a). American circumstance. Rotterdam, The Netherlands: Sense Publishers. 
Leavy, P. (2013b). Fiction as research practice: Short stories, novellas and novels. Walnut Creek, CA: Left Coast Press.

Leavy, P. (2015a). Blue. Rotterdam, The Netherlands: Sense Publishers.

Leavy, P. (2015b). Method meets art: Artsbased research practice (Second edition). New York: Guilford Press.

Nieckarz, P. P. Jr. (2008). Science fiction as social fact: Review and evaluation of the use of fiction in an introductory sociology class. In C. C. Irvine (Ed.), Teaching the novel across the curriculum: A handbook for educators (pp. 231-247). Westport, CT: Greenwood Press.
Thompson, H., \& S. Vedantam. (2012). "A lively mind: Your brain on Jane Austen." NPR Health Blog. Retrieved from http://www.npr. org/blogs/health/2012/10/09/162401053/alively-mind-your-brain-on-jane-austen. html.

Tucker. W. M. (1994). Teaching psychiatry through literature: The short story as case history. Academic Psychiatry, 18, 211-219.

Wolff, K. B. (2008). Reading our social worlds: Utilizing novels in introduction to sociology courses. In C. C. Irvine (Ed.), Teaching the novel across the curriculum: A handbook for educators (pp. 219-230). Westport, CT: Greenwood Press.

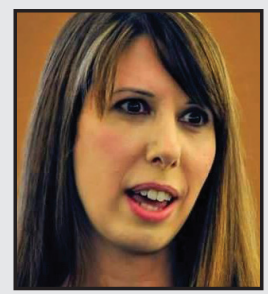

Patricia Leavy, $\mathrm{PhD}$, is an independent scholar (formerly Associate Professor of Sociology, Chair of Sociology \& Criminology and Founding Director of Gender Studies at Stonehill College). Her 19 published books include Method Meets Art: Arts-Based Research Practice (first and second editions), The Oxford Handbook of Qualitative Research, Fiction as Research Practice, Essentials of Transdisciplinary Research, and the bestselling novels Blue, Low-Fat Love: Expanded Anniversary Edition, and American Circumstance. She is series editor for six book series including Social Fictions, Personal/Public Scholarship, Teaching Gender, Teaching Race \& Ethnicity and Teaching Writing for Sense Publishers, and Understanding Qualitative Research for Oxford University Press. She has regular blogs for The Huffington Post, The Creativity Post, and We Are the Real Deal. 